\title{
Potential Risk Assessment of Cardiovascular Disease in Low Calcium-Score
}

\author{
Heangsoo Yoo*, Jikoon Park ${ }^{* *}$, Bongjae Jung ${ }^{* *}$, Sicheol Noh ${ }^{* *}$, IlhHong Choi*, \\ Hyungjn Jung ${ }^{* *}$, Sangsik Kang** \\ Department of Radiology, Samsungchangwon Hospital* \\ Department of Radiological Science, International University of Korea** \\ 낮은 칼슘 수치에서 심혈관질환의 잠재 위험도 평가 \\ 유행수 ${ }^{*}$, 박지군**, 정봉재**, 노시철**, 최일홍**, 정형진 ${ }^{* *}$, 강상식 ${ }^{* *}$ \\ 삼성창원병원 영상의학과*, 한국국제대학교 방사선학과**
}

\begin{abstract}
Prepared her for the early detection of the risk of cardiovascular disease prevention for the various attempts being made ill through a lot of research to the criteria of coronary artery calcification, but the figure is more than 100 the progress of the flow can be expected to bewas. In this study, we quantify the correlation between body composition analysis, blood lipid levels of calcium and public asymptomatic even at low calcium levels in comparison with the existing studies by analyzing potential risk of cardiovascular disease will be represented on thewere evaluated. Studies, the calcium scores in the body composition analysis "1-10", and when "11-100" when there was a significant correlation in BMI and WHR look more normal frequency range of the mean values in the normal range meomulreoteuna $21 \%$ relativeHDL and TG in lipid profiles, no significant correlation look more normal frequency range of risk were derived from the mean values in the normal range, $21 \%$ to $40 \%$ of the relative risk were derived. meomulreoteuna. In addition, there is no correlation between BFM and BMR Also, average increases in the frequency of a higher standard was higher relative risk derived 31 to $93 \%$, and geological correlation test TC above $20 \mathrm{mg} / \mathrm{dl}$ atherosclerotic sclerosisseems to be the value of HDL to act to remove cholesterol from atheroma already looking at the same time to suppress the occurrence of atherosclerosis, increased LDL showed higher values occurs rapidly increasing. At this time, the relative risk of $43-50 \%$ have been identified. In other words, even when calcium levels are low, that is inherent in the incidence of cardiovascular disease was unknown.
\end{abstract}

Key words: Potential Risk Assessment of Cardiovascular Disease, Calcium-score, body composition index, test for lipid metabolism, sensitivity

\section{요 야}

심혈관 질환의 위험도를 조기에 발견해 예방하기 위한 다양한 시도들이 이루어지고 있는 데 질환자를 대상으로 한 많은 연구를 통해 관상동맥 석회화의 판정기준이 마련되었으나 수치가 100 이상이 되어야 진행의 흐름을 예상할 수 있었다. 이에 본 연구는 자각증상이 없는 일반인을 대상으로 칼슘 수치와 체성분 분석, 혈중지질 수치의 상관관계를 수 치화하여 기존 연구와 비교분석하여 칼슘 수치가 낮을 때에도 잠재적인 심혈관 질환의 위험성을 나타낼 수 있을지에 
대한 평가를 해 보았다. 연구 결과 체성분 분석에서 칼슘수치가 0-10일 때 와 칼슘수치가 11-100일 때 유의한 상관 관계가 있는 $\mathrm{BMI}$ 와 $\mathrm{WHR}$ 을 살펴보면 정상범위의 빈도수가 많아 평균값이 정상범위에 머물렀으나 $21 \%$ 의 상대적인 위 험률이 도출되었으며 지질검사에서도 유의한 상관관계가 있는 $\mathrm{HDL}$ 과 $\mathrm{TG}$ 를 살펴보면 정상범위의 빈도수가 많아 평균 값이 정상범위에 머물렀으나 21-40\%의 상대적인 위험률이 도출되었다. 또한 상관관계가 없는 $\mathrm{BFM}$ 과 $\mathrm{BMR}$ 에서는 표 준이상에서 빈도수가 높아 평균값도 높게 나타났으며 상대적 위험도가 31-93\%로 도출되었으며 지질검사에서 상관관 계가 없는 $\mathrm{TC}$ 가 $200 \mathrm{mg} / \mathrm{dl}$ 이상으로 죽상동맥경화증의 발생이 급격히 증가하여 $\mathrm{LDL}$ 값이 높게 나타났으며 죽상경화증 의 발생을 억제하기 위해 이미 생긴 죽종에서 콜레스테롤을 제거하는 작용을 하는 $\mathrm{HDL}$ 의 값도 동시에 증가한 것으로 보인다. 이 때의 상대적 위험률은 43-50\%로 도출되었다. 즉 칼슘 수치가 낮을 때에도 심혈관 질환의 발생률이 내재되 어 있음을 알 수 있었다.

중심단어 : 심혈관 질환의 위험도, 칼슘수치, 체성분 분석, 혈중 지질 수치, 민감도

\section{I. 서 론}

최근 들어 생활양식의 서구화 및 인구의 고령화로 인하여 심혈관 질환의 빈도와 사망률이 과거에 비해 급속도록 증가하고 있다. 심혈관 질환은 전 세계 1,2 위 주요 사망원인으로 우리나라에서 1999년-2009년 동 안 사망원인의 3 위를 차지하였고, 특히 50 대 이하는 심장질환이, 60 대 이상은 순환기 질환이 가장 높은 것 으로 나타났다 ${ }^{[1]}$. 이에 심혈관 질환의 위험도를 조기 에 발견해 예방하기 위한 다양한 시도들이 이루어지 고 있다. 관상동맥 칼슘수치는 관상동맥의 동백경화반 의 총량과 비례하고, 관상동맥의 협착을 예측하는 지 표라는 주장도 있고 ${ }^{[1],[2]}$, 관상동맥 칼슘수치가 허혈성 심장질환 발생의 독립적인 위험인자로 향후 관상동맥 질환의 발생률과 관련이 있으며 이는 심혈관 질환의 단기간의 예측인자로서 전통적인 다른 위험인자보다 우수하다고 보고되고 있다 ${ }^{[3]-[8]}$. 현재 칼슘수치를 이용 한 관상동맥 석회화의 판정기준은 칼슘수치 (Calcium-score)가 10 이하는 심각한 강내 폐색이 거의 없는 수준, 100 이상은 협착의 진행을 예상할 수 있고 400 이상은 $50 \%$ 의 환자에게서 하나의 혈액이 흐름의 지장을 받는 것으로 보고되어 있다. 이렇듯 전체적인 수치의 변화에 따른 심혈관질환 발생률에 관련된 연 구는 지속적으로 이루어져 있으나 칼슘수치가 100 이 하에서는 심혈관 질환의 예상에 대한 연구가 부족한 실정이다. 황[9]의 연구에서는 심혈관 질환의 위험인자 로 총콜레스테롤, 중성지방, 체질량지수 등을 제시하 였고 상관관계가 높다는 연구들이 발표되고 있다. 이 에 본 연구에서는 낮은 칼슘수치에서 심혈관질환과
관계가 있는 체질량지수와 지질대사와의 상관관계를 분석하여 심혈관질환의 위험도를 평가해 보고자 한다.

\section{II. 연구방법}

\section{1. 연구대상}

2011년 1월 1일에서 9월 30일까지 본원의 종합검진 대상자 중 Calcium-scoring CT 검사를 선택한 수검자들 을 대상으로 하였다. 관상동맥성 심질환의 여러 위험 요인 중 흡연은 가장 조절 가능한 위험요인으로 알려 져 있다. Framingham 연구 등을 포함한 Pooling Project 연구결과는 다른 위험요인들을 제외한 경우 흡연자의 비흡연자에 비한 허혈성 심장질환의 위험률이 2 3배 가량 높음을 보여주었고 ${ }^{[10]}$ 체질량지수(Body mass index; BMI $)^{[11]}$ 구분에 따른 남녀의 차이가 크지 않으 며 지질검사에서는 여자보다 남자에서 유의하게 높게 나타나는 박 ${ }^{[12]}$ 의 연구를 기반으로 연구의 목적에 부 합한 결과를 도출하기 위한 목적으로, 상기 검사 중 관상동맥 기왕자 또는 심혈관계 약물 복용자, 흡연자 등의 이상이 인정된 자를 제외 한 40 70세 사이의 남 자 총 85 명에 대한 데이터를 분석하였다.

\section{2. 검사장비}

128 channel SOMATOM Definition AS+ CT (Siemens 사, Germany)를 사용하였고 영상관리 Software는 Aquarius (iNtution Edition version 4.4.6, Terarecon 주식 회사)를 사용하였다. 인체 지수를 측정하기 위한 장비 는 정밀 체성분 분석기로 INBODY 720(바이오스페이 스(주))을 사용하였으며 혈액학적 및 혈액생화학적 지 
표의 측정은 피검자들을 검사 전날 오후 10 시부터 금 식한 상태로 검사 당일 오전에 상완정맥에서 채혈하 였으며, 총콜레스테롤(TC), 고밀도콜레스테롤(HDL), 중성지방(TG)은 원심분리기 MF300 (Hanil Science Industrial)을 사용하여 측정하였고, 저밀도콜레스테롤 (LDL)은 Friedwald의 공식(LDL=TC-HDL-TG/5)에 의해 산출하였다 ${ }^{[14]}$.

\section{3. 자료의 분석}

이 연구에서 사용되는 연구방법은 Calcium-score 수 치가 1 100 에서와 증가 할 때 체성분과 지질대사의 상관관계를 분석하여 심혈관질환의 가능성을 평가하 고자 한다. 측정도구는 Calcium-scoring CT를 시행한 종 검 수진자를 대상으로 칼슘수치에 따른 체성분과 지 질대사검사수치를 비교분석하고 칼슘수치가 1 100일 때 체성분과 지질대사 검사수치를 비교 분석하며 통 계프로그램을 이용하여 상관관계를 분석하였다.

\section{III. 연구결과}

\section{1. 칼슘수치에 따른 체성분 분석}

Table 1은 In-Body에서 제시하는 체성분 분석항목 (BMI, $\mathrm{BFM}, \mathrm{BMR}, \mathrm{WHR}$ )을 기준으로 측정한 빈도수로 칼슘 수치가 0-10일 때 체질량지수가 18.5미만에서 3 명, 18.5-24.9의 정상범위에서 21명 $(65.6 \%)$ 으로 가장 많 았으며, 25-29.9에서는 8명, 30이상은 없었다. 체지방에 서는 표준범위(15\%)에서 21명(65.6\%), 표준이상 $(15 \%$ 이 상)에서 11 명으로 나타나 표준범위가 2 배가량 많았으 며, 체지방률에서는 표준범위 $(15 \%)$ 에서 7 명, 표준이상 $(15 \%$ 이상 $)$ 에서 25 명으로 표준이상이 $78.1 \%$ 를 차지했 다. 허리 둘레비를 보면 0.90 미만이 25명(78.1\%)으로 나 머지 7 명이 0.90 이상으로 나타났다. 체질량지수, 체지 방량, 허리둘레비는 정상범위가 많았으며 체지방률만 이 표준이상의 사람이 많았다. 칼슘수치가 11-100 일 때 체질량지수가 18.5 미만과 30 이상은 없었고, 18.5-24.9에서는 22명 $(69 \%)$ 으로 가장 많이 분포했고, 25-29.9인 과체중에서는 10명으로 나타났다. 체지방에 서 표준범위에서는 14명, 표준이상이 18명으로 나타났 고, 체지방률에서는 표준범위에서 2 명, 표준이상이 30
명으로 $93.8 \%$ 로 많이 분포하였다. 허리둘레비에서는 0.90 미만과 0.90 이상에서 16 명 $(50 \%)$ 으로 나타났다.

Table 1. Frequency number of body composition according to calcium-score

\begin{tabular}{|c|c|c|c|}
\hline $\begin{array}{l}\text { 칼슘 } \\
\text { 수치 }\end{array}$ & 변수 & 수 준 & 빈도 및 값(\%) \\
\hline \multirow{10}{*}{$0-10$} & \multirow{4}{*}{ BMI } & 18.5 & $3(9.4)$ \\
\hline & & 18.5 24.9(정상) & $21(65.6)$ \\
\hline & & 25.0 29.9(과체중) & $8(25)$ \\
\hline & & 30.0 34.9(비만1) & $x$ \\
\hline & \multirow{2}{*}{$\mathrm{BFM}$} & 표준범위(남성 15 \%) & $21(65.6)$ \\
\hline & & 표준이상(남성 $15 \%$ 이상) & 11(34.4) \\
\hline & \multirow{2}{*}{ BMR } & 표준범위(남성 15 \%) & $7(21.9)$ \\
\hline & & 표준이상(남성 $15 \%$ 이상) & $25(78.1)$ \\
\hline & \multirow{2}{*}{ WHR } & 0.90 미만 & $25(78.1)$ \\
\hline & & 0.900 이상 & $7(21.9)$ \\
\hline \multirow{10}{*}{$11-100$} & \multirow{4}{*}{ BMI } & 18.5 & $x$ \\
\hline & & 18.5 24.9(정상) & $22(69)$ \\
\hline & & 25.0 29.9(과체중) & 10(31) \\
\hline & & 30.0 34.9(비만1) & $x$ \\
\hline & \multirow{2}{*}{ BFM } & 표준범위(남성 15 \%) & 14(43.8) \\
\hline & & 표준이상(남성 $15 \%$ 이상) & 18(56.2) \\
\hline & \multirow{2}{*}{ BMR } & 표준범위(남성 15 \%) & $2(6.2)$ \\
\hline & & 표준이상(남성 $15 \%$ 이상) & $30(93.8)$ \\
\hline & \multirow{2}{*}{ WHR } & 0.900 미만 & $16(50)$ \\
\hline & & 0.900 이상 & $16(50)$ \\
\hline \multirow{10}{*}{$\begin{array}{c}101 \\
\text { 이상 }\end{array}$} & \multirow{4}{*}{ BMI } & 18.5 & $x$ \\
\hline & & 18.5 24.9(정상) & $8(38)$ \\
\hline & & 25.0 29.9(과체중) & $12(57)$ \\
\hline & & 30.0 34.9(비만1) & $1(5)$ \\
\hline & \multirow{2}{*}{ BFM } & 표준범위(남성 $15 \%$ ) & $4(19)$ \\
\hline & & 표준이상(남성 $15 \%$ 이상) & $17(81)$ \\
\hline & \multirow{2}{*}{ BMR } & 표준범위(남성 15 \%) & $x$ \\
\hline & & 표준이상(남성 $15 \%$ 이상) & $21(100)$ \\
\hline & \multirow{2}{*}{ WHR } & 0.900 만 & $8(38.1)$ \\
\hline & & 0.900 이상 & 13(61.9) \\
\hline
\end{tabular}

과체중이 많고 체지방과 체지방률은 표준이상에 많 이 분포하고 복부비만도는 $50 \%$ 로 나타났다. 칼슘수치 가 101 이상 일 때 체질량지수가 18.5미만은 없었으며 18.5-24.9인 정상범위는 8명, 25-29.9인 과체중에서는 12 명 $(57 \%)$ 으로 가장 많이 분포했고, 30 이상의 비만범위 에서는 1 명으로 나타났다. 체지방에서는 표준범위에서 4명, 표준이상에서 13명으로 나타나고 체지방률에서는 21 명이 모두 표준이상으로 나타났다. 복부비만도에서 는 90미만이 8명, 90이상이 13명 $(61.9 \%)$ 으로 나타났다. 과체중이 많고 체지방, 체지방률, 복부비만도 모두 표 준이상에 많이 분포하였다. 
Table 2. Test for difference in body composition according to calcium-score

\begin{tabular}{c|ccccc}
\hline & $\begin{array}{c}0-10 \\
M(S D)\end{array}$ & $\begin{array}{c}11-100 \\
M(S D)\end{array}$ & t값 & $\begin{array}{c}P \\
\text { (유의확률) }\end{array}$ & $\begin{array}{c}\text { 심혈관 } \\
\text { 질환자 } \\
\text { 평균값(M) }\end{array}$ \\
\hline 평균값 & $\begin{array}{cccccc}22.82 \\
\text { BMI }\end{array}$ & $\begin{array}{c}24.43 \\
(1.92)\end{array}$ & -2.503 & $.015 *$ & 26.31 \\
\hline \multirow{2}{*}{$B F M$} & $\begin{array}{c}13.36 \\
(5.30)\end{array}$ & $\begin{array}{c}15.36 \\
(3.98)\end{array}$ & -1.713 & .138 & 27.35 \\
\hline \multirow{2}{*}{ BMR } & $\begin{array}{c}19.74 \\
(5.47)\end{array}$ & $\begin{array}{c}21.56 \\
(4.16)\end{array}$ & -1.502 & .138 & 20.65 \\
\hline \multirow{2}{*}{ WHR } & $\begin{array}{c}0.86 \\
(0.04)\end{array}$ & $\begin{array}{c}0.88 \\
(0.03)\end{array}$ & -2.835 & $.007 * *$ & 0.90 \\
\hline
\end{tabular}

$\mathrm{t}=\mathrm{t}$-value, $\mathrm{P}=$ 유의수준 $(0.05 *, 0.01 * *)$

Table 2는 종합검진 수검자 중에서 Calcium-scroring CT를 시행한 85 명의 체성분 결과를 칼슘수치에 어떠 한 영향을 미치는가에 대한 차이검정을 한 것이다. BMI 에서 칼슘수치가0-10 일 때 $\mathrm{M}=22.82, \mathrm{SD}=3.09$ 이 고 10-100일 때 $\mathrm{M}=24.43, \mathrm{SD}=1.91$ 로 칼슘수치가 증가 할수록 $\mathrm{BMI}$ 값이 증가하는 것을 확인할 수 있었으며 통계학적으로 유의한 결과를 도출하였다. 체지방(Body fat mass)에서 칼슘수치가 $0-10$ 일 때 $\mathrm{M}=13.36, \mathrm{SD}=5.29$ 이었으나 10-100일 때 $\mathrm{M}=15.36, \mathrm{SD}=3.98$ 로 표준이상을 타나내며 칼슘수치가 증가할수록 체지방이 증가하는 것을 확인할 수 있었으나 통계학적으로 유의하지 않 는 결과를 도출하였다. 체지방률(Body mass index; $\mathrm{BMR}$ )은 칼슘수치가 $0-10$ 일 때 $\mathrm{M}=19.74, \mathrm{SD}=5.47$ 이고 칼슘수치가 11-100일 때 $\mathrm{M}=21.56, \mathrm{SD}=4.15$ 로 표준이상 으로 나타났고 차이가 높지 않았으며 유의하지 않는 결과를 도출하였다. 복부비만도(Waist-hip ratio; WHR) 에서는 칼슘수치가 $0-10$ 에서 $\mathrm{M}=.86, \mathrm{SD}=.04$ 이고 칼슘 수치가 $11-100$ 에서 $\mathrm{M}=.88, \mathrm{SD}=.02$ 로 칼슘수치가 증가 할수록 $\mathrm{WHR}$ 이 증가하는 것을 확인 할 수 있었고 차 이가 높지 않았으며 통계적으로 유의하였다. 낮은 칼 슘수치에 따른 체성분 분석을 통해 체지방, 체지방률 을 제외한 체질량지수와 복부비만도가 영향을 미치는 것으로 나타났다.

Fig. 1은 비교대상으로 추가한 심혈관 질환자 30 명 의 평균치를 분석한 것이다. 칼슘 수치가 $0-10$ 에서는 비만판정의 필수 요소인 체지방률이 표준 이상(19.74) 으로 나타났으나 체질량지수(22.83)와 체지방(13.36), 복 부비만도(0.86)는 정상범위에 있었으며 칼슘 수치가
11-100에서는 복부비만도(0.89)만이 정상범위이고 나머 지 체질량지수(24.44), 체지방(15.37), 체지방률(21.57)이 모두 정상범위보다 높게 나타났다. 심혈관계 질환자의 체성분 평균값은 체질량지수(26.31), 체지방(20.65), 체 지방률(27.35)이 표준이상으로 나타났고 복부비만도 $(0.90)$ 는 정상으로 나타났다.

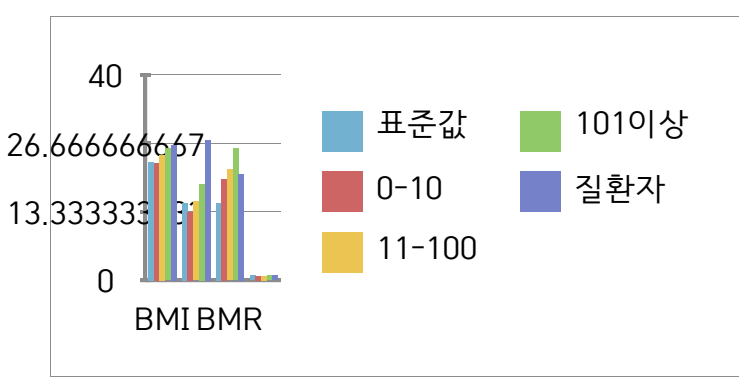

Fig. 1. Evaluation of body composition according to calcium-score.

Table 3은 수검자들을 칼슘수치에 따라 체성분 분석 의 상대적 위험률을 산출한 것이다. 그러나 대상자에 서 비만수가 1 명이라 BMI는 제외하고 각각 체성분의 표준이상의 위험수치에 있는 인원수를 위험군(A), 정 상범위에 있는 인원수를 비위험군(B)으로 두고 상대적 위험률 $(\mathrm{A} / \mathrm{A}+\mathrm{B} \times 100)$ 을 도출했다. 칼슘수치가 $0-10$ 일 때 총 32 명 중 $\mathrm{BFM}$ 은 10명, BMR은 24명, WHR는 7명 으로 $21-75 \%$ 의 상대적인 위험률을 보였다. 칼슘 수치 가 11-100일 때 총 32명 중 체지방은 16 명, 체지방률은 30 명, 복부비만도는 16명으로 50-93\%의 상대적인 위험 률을 보였다. 전체적으로 보면 낮은 칼슘수치에서 상 대적인 위험률이 $12-75 \%$ 로 나타났다. 이는 칼슘수치는 낮지만 심혈관질환의 발병률이 잠재되어 있음을 보여 주고 있다.

Table 3. Relative risk of body composition analysis

\begin{tabular}{c|cccc}
\hline 칼슘수치 & 구 분 & 위험군(A) & 비위험군(B) & $\mathrm{A} / \mathrm{A}+\mathrm{B} * 100$ \\
\hline \multirow{3}{*}{$0-10$} & $\mathrm{BFM}$ & 24 & 8 & 75 \\
\cline { 2 - 5 } & $\mathrm{BMR}$ & 10 & 22 & 31 \\
\cline { 2 - 5 } & $\mathrm{WHR}$ & 7 & 25 & 21 \\
\hline \multirow{3}{*}{$11-100$} & $\mathrm{BFM}$ & 30 & 2 & 93 \\
\cline { 2 - 5 } & $\mathrm{BMR}$ & 16 & 16 & 50 \\
\cline { 2 - 5 } & WHR & 16 & 16 & 50 \\
\hline \multicolumn{4}{|c}{}
\end{tabular}

칼슘 수치와 체성분 분석의 상관관계를 분석한 결 과는 Table 4에서 보는 바와 같이 각각의 칼슘 수치에 
따른 상관관계를 보면 체질량지수(.387), 복부비만도 (.406)가 양(+)의 값을 보이고 체지방(.220), 체지방률 (.225)은 유의하지 않는 양(+)의 상관관계로 나타났다. 체질량지수에서는 체지방(.691), 체지방률(.334), 복부비 만도(.609)가 양(+)의 상관관계를 보였다. 체지방에서는 체지방률(.368), 복부비만도(.430)가 양(+)의 값을 보였 으며 체지방률을 기준으로 보면 복부비만도(.519)는 양 $(+)$ 의 상관관계로 나타났다. 칼슘 수치를 기준으로 상 관관계를 분석해 보면 유의수준 0.01 이하에서 도출되 었으며 체지방과 체지방률을 제외하고는 유의한 양(+) 의 상관관계로 분석되었다.

Table 4. Correlation between calcium-score and body composition

\begin{tabular}{c|ccccc}
\hline 구 분 & 칼슘수치 & $\mathrm{BMI}$ & $\mathrm{BFM}$ & $\mathrm{BMR}$ & $\mathrm{WHR}$ \\
\hline 칼슘수치 & 1 & & & & \\
\hline $\mathrm{BMI}$ & $.387 \star \star$ & 1 & & & \\
\hline $\mathrm{BFM}$ & .220 & $.691 \star \star$ & 1 & & \\
\hline $\mathrm{BMR}$ & .225 & $.334 \star \star$ & $.368 \star \star$ & 1 & \\
\hline $\mathrm{WHR}$ & $.406 \star \star$ & $.609 \star \star$ & $.430 \star \star$ & $.519 \star \star$ & 1 \\
\hline \multicolumn{7}{c}{$\mathrm{P}=$ 유의수준 $(0.05 *}$, & $0.01 \star \star$
\end{tabular}

\section{2. 칼슘 수치에 따른 지질대사 분석}

Table 5는 혈액지질 대사 분석항목(TC, HDL, LDL, $\mathrm{TG})$ 을 기준으로 측정한 빈도수로 칼슘수치가 0-10일 때 총 32명중 총콜레스테롤치가 200미만은 15명, 200 이상은 17 명(53.1\%)으로 표준이상이 더 많았고 고밀도 콜레스테롤에서는 심장질병의 위험이 높은 40 미만은 없었고 정상수치인 40에서 14명, 심질환 발병률을 낮 출 수 있는 60 이상에서 18명(56.2\%)으로 나타났다. 저 밀도 콜레스테롤에서는 100미만이 2명, 100-129인 정상 범위가 14명, 130 이상으로 상당히 높은 사람이 16명 $(50 \%)$ 으로 나타났다. 중성지방에서는 150 미만의 정상 치에서는 28 명 $(87.5 \%)$ 으로 가장 많이 분포했고 150 이 상에서는 4명으로 나타났다. 칼슘 수치가 11-100일 때 총 31 명 중 총콜레스테롤치가 200미만은 13명, 200이 상은 19명(59.4\%)으로 표준이상이 더 많았고 고밀도콜 레스테롤에서는 40미만은 7명, 정상수치인 40에서 13 명(40.6\%)으로 가장 많이 분포하였고, 60 이상에서는 12 명이었다. 저밀도 콜레스테롤에서는 100미만이 7명,
100-129인 정상범위가 10 명, 130 이상으로 상당히 높은 사람이 15 명 $(46.9 \%)$ 으로 나타났다. 중성지방에서는 150 미만의 정상치에서는 19 명(59.4\%)이고 150 이상에서는 13명으로 나타났다. 칼슘 수치가 101이상에서는 총 21 명 중 총콜레스테롤치가 200미만은 7명, 200이상은 14 명 $(66.7 \%)$ 으로 표준이상이 더 많았고 고밀도콜레스테 롤에서는 40 미만은 2 명, 정상수치인 40 에서 8 명이고, 60 이상에서는 11 명 $(52.4 \%)$ 으로 가장 많이 분포하였다.

Table 5. Frequency number of lipid metabolism value according to calcium-score

\begin{tabular}{|c|c|c|c|}
\hline & & & $n=8$ \\
\hline 칼슘 수치 & 변 수 & 수 준 & 빈도 및 값(\%) \\
\hline \multirow{10}{*}{$0-10$} & \multirow{2}{*}{ TC } & 200미만 & $15(46.9)$ \\
\hline & & 2000이상 & 17(53.1) \\
\hline & \multirow{3}{*}{ HOL } & 40미만 & $x$ \\
\hline & & 40 & 14(43.8) \\
\hline & & 60이상 & $18(56.2)$ \\
\hline & \multirow{3}{*}{ LDL } & 100미만 & $2(6.2)$ \\
\hline & & $100-129$ & $14(43.8)$ \\
\hline & & 1300이상 & $16(50)$ \\
\hline & \multirow{2}{*}{ TG } & 150미만 & 28(87.5) \\
\hline & & 150이상 & $4(12.5)$ \\
\hline \multirow{10}{*}{$11-100$} & \multirow{2}{*}{$\mathrm{TC}$} & 200미만 & $13(40.6)$ \\
\hline & & 2000이상 & 19(59.4) \\
\hline & \multirow{3}{*}{ HDL } & 40미만 & $7(21.9)$ \\
\hline & & 40 & $13(40.6)$ \\
\hline & & 60 이상 & 12(37.5) \\
\hline & \multirow{3}{*}{ LDL } & 100미만 & 7(21.9) \\
\hline & & $100-129$ & 10(31.3) \\
\hline & & 1300이상 & $15(46.9)$ \\
\hline & \multirow{2}{*}{ TG } & 150미만 & 19(59.4) \\
\hline & & 150 이상 & $13(40.6)$ \\
\hline \multirow{10}{*}{$\begin{array}{c}101 \\
\text { 이상 }\end{array}$} & \multirow{2}{*}{ TC } & 200미만 & $7(33.3)$ \\
\hline & & 2000이상 & $14(66.7)$ \\
\hline & \multirow{3}{*}{ HDL } & 40미만 & $2(9.5)$ \\
\hline & & 40 & $8(38.1)$ \\
\hline & & 60 이상 & 11(52.4) \\
\hline & \multirow{3}{*}{ LDL } & 100미만 & $5(23.8)$ \\
\hline & & $100-129$ & $4(19)$ \\
\hline & & 1300이상 & $12(57.1)$ \\
\hline & \multirow{2}{*}{ TG } & 150미만 & 13(61.9) \\
\hline & & 1500이상 & $8(38.1)$ \\
\hline
\end{tabular}

저밀도 콜레스테롤에서는 100미만이 5명, 100-129인 정상범위가 4명, 130 이상으로 상당히 높은 사람이 12 명 $(57.1 \%)$ 으로 나타났다. 중성지방에서는 150 미만의 정 상치에서는 13 명 $(61.9 \%)$ 이고 150 이상에서는 8 명으로 나타났다. 세 범위 모두에서 총콜레스테롤과 저밀도콜 레스테롤이 높은 사람이 많았고 고밀도콜레스테롤과 중성지방이 낮은 사람이 많았다. 
종합검진 수검자 중에서 Calcium-scroring CT를 시행 한 85 명의 체성분 결과를 칼슘수치에 어떠한 영향을 미치는가에 대한 차이검정인 Table 6에서 보면 총콜레 스테롤(TC)에서 칼슘수치가 0-10 일 때 $\mathrm{M}=209.63$, $\mathrm{SD}=35.07$ 로 표준이상으로 나타났고 10-100일 때 $(\mathrm{M}=206.47, \mathrm{SD}=38.80)$ 보다 높게 나타났으나 차이가 높 지 않았고 통계학적으로 유의하지 않는 결과를 도출 하였다. 고밀도콜레스테롤(HDL)에서 칼슘수치가 0-10 일 때 $\mathrm{M}=62.78, \mathrm{SD}=12.73$ 으로 심장질환의 발병률을 낮 출 수 있는 수준으로 나타났고 10-100일 때 $\mathrm{M}=54.91$, $\mathrm{SD}=16.48$ 로 통계학적으로 유의하였다. 저밀도콜레스테롤 (LDL)은 칼슘수치가 0-10일 때 $(\mathrm{M}=138.16, \mathrm{SD}=35.54)$ 가 칼슘수치가 11-100일 때 $(\mathrm{M}=131.03, \mathrm{SD}=33.67)$ 보다 높 게 나타났으나 두 구간 모두 심혈관 질환의 발병률이 높은 수준으로 나타났고 차이가 높지 않았으며 유의 하지 않는 결과를 도출하였다. 중성지방(TG)에서는 칼 슘수치가 $0-10$ 에서 $\mathrm{M}=98.41, \mathrm{SD}=45.72$ 이고 칼슘수치가 11-100에서 $\mathrm{M}=155.38, \mathrm{SD}=92.33$ 으로 칼슘수치가 증가 할수록 중성지방이 증가하는 것을 확인 할 수 있었고 통계적으로 유의하였다. 낮은 칼슘수치에 따른 지질검 사를 통해 콜레스테롤, 저밀도콜레스테롤을 제외한 고 밀도콜레스테롤과 중성지방이 영향을 미치는 것으로 나타났으며 유의한 수준을 보였다. Fig 2에서 보면 칼 슘수치의 증가에 따라 중성지방만이 비례적인 증가가 이루어졌고 칼슘수치에 따라(0-10/11-100) 총콜레스테 롤이 209.63/206.47, 저밀도콜레스테롤이 138.16/ 131.03 로 정상치보다 높게 나타났고 중성지방이 98.41/155.38 로 나타났으며 고밀도콜레스테롤은 심혈관질환의 발 병률을 낮출 수 있는 수치로 나타났다.

Table 6. Test for difference in lipid metabolism according to calcium-score

\begin{tabular}{|c|c|c|c|c|c|}
\hline & $\begin{array}{r}1-10 \\
M(S D)\end{array}$ & $\begin{array}{l}11-100 \\
M(S D)\end{array}$ & $\mathrm{t}$ 값 & $\begin{array}{c}P \\
\text { (유의확률) }\end{array}$ & $\begin{array}{c}\text { 심혈관 } \\
\text { 질환자 } \\
\text { 평균값 }(\mathrm{M})\end{array}$ \\
\hline TC & $\begin{array}{l}209.63 \\
(35.08)\end{array}$ & $\begin{array}{l}206.47 \\
(38.81)\end{array}$ & .341 & .734 & 230.8 \\
\hline HOL & $\begin{array}{c}62.78 \\
(12.73)\end{array}$ & $\begin{array}{c}54.91 \\
(16.49)\end{array}$ & 2.138 & $.036 \star \star$ & 54.2 \\
\hline LDL & $\begin{array}{r}138.16 \\
(35.55)\end{array}$ & $\begin{array}{r}131.03 \\
(33.68)\end{array}$ & .823 & .414 & 144 \\
\hline $\mathrm{TG}$ & $\begin{array}{c}98.41 \\
(45.73)\end{array}$ & $\begin{array}{c}155.38 \\
(92.34)\end{array}$ & -3.128 & $.003 * \star$ & 261.3 \\
\hline
\end{tabular}

심혈관계 질환자들의 평균값은 총콜레스테롤(230.8), 저밀도콜레스테롤(144), 중성지방(261.3)이 표준이상으로 나타났으나 고밀도콜레스테롤(54.2)은 정상수치였다.

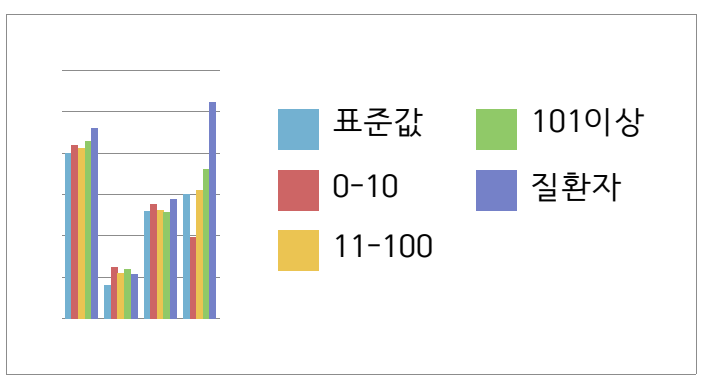

Fig. 2. Evaluation of lipid metabolism according to calcium-score.

Table 7은 Table 3 과 같은 방법으로 수검자들의 칼슘 수치에 따라 지질대사 값의 상대적 위험률을 산출한 것이다. 칼슘수치가 0-10일 때 총 32명 중 총콜레스테롤 (TC)은 16 명, 저밀도콜레스테롤 $(\mathrm{LDL})$ 은 16 명, 중성지방 (TG)은 4명으로 $12-50 \%$ 의 위험률로 나타났다. 칼슘수 치가 11-100일 때 총 32명 중 총콜레스테롤은 19명, 고 밀도콜레스테롤은 7명, 저밀도콜레스테롤은 14명, 중 성지방은 13명으로 $21-59 \%$ 의 상대적인 위험률을 보였 다. 전체적으로 보면 낮은 칼슘수치에서 상대적인 위 험률이 $12-59 \%$ 로 나타났다. 이는 칼슘수치는 낮지만 심혈관질환의 발병률이 잠재되어 있음을 보여주고 있다.

Table 7. Relative risk of lipid metabolism value

\begin{tabular}{c|cccc}
\hline 칼슘수치 & 구 분 & 위험군(A) & 비위험군(B) & $\mathrm{A} / \mathrm{A}+\mathrm{B} * 100$ \\
\hline \multirow{3}{*}{$0-10$} & $\mathrm{TC}$ & 16 & 16 & 50 \\
\cline { 2 - 5 } & $\mathrm{LL}$ & 16 & 16 & 50 \\
\cline { 2 - 5 } & $\mathrm{TG}$ & 4 & 18 & 12 \\
\hline \multirow{4}{*}{$11-100$} & $\mathrm{TC}$ & 19 & 13 & 59 \\
\cline { 2 - 5 } & $\mathrm{HDL}$ & 7 & 25 & 21 \\
\cline { 2 - 5 } & $\mathrm{LDL}$ & 14 & 18 & 43 \\
\cline { 2 - 5 } & $\mathrm{TG}$ & 13 & 19 & 40 \\
\hline
\end{tabular}

칼슘 수치와 지질대사 분석의 상관관계를 분석한 결과인 Table 8에서 보면 총콜레스테롤(.063)이 양(+)의 값으로 저밀도콜레스테롤(-132)로 음(-)의 값으로 유의 하지 않게 나타났고 고밀도콜레스테롤(-.303)은 음(-)의 상관관계로 중성지방(.318)은 양(+)의 값으로 유의성 있게 나타났다. 총콜레스테롤에서는 고밀도콜레스테 롤(.003)은 유의하지 않는 양(+)의 상관관계로 나타났 
고 저밀도콜레스테롤(.736), 중성지방(.316)이 유의한 양 (+)의 상관관계를 보였으며 고밀도콜레스테롤에서는 저밀도콜레스테롤(-.095)이 유의하지 않는 음(-)의 상관 관계를 중성지방(-.323)이 유의한 음(-)의 값을 보였다. 저밀도콜레스테롤에서는 중성지방(.207)이 양(+)의 상 관관계를 보였다. 칼슘 수치를 기준으로 상관관계를 분석해 보면 유의수준 0.05 이하에서 도출되었으며 총 콜레스테롤과 저밀도콜레스테롤을 제외하고는 고밀도 콜레스테롤은 음(-)의, 중성지방은 양(+)의 유의한 상 관관계로 분석되었다.

Table 8. Correlation between calcium-score and lipid metabolism

\begin{tabular}{c|ccccc}
\hline 구 분 & $\begin{array}{c}\text { 칼슘 } \\
\text { 수치 }\end{array}$ & TC & HDL & LDL & TG \\
\hline 칼슘 수치 & 1 & & & & \\
\hline TC & .063 & 1 & & & \\
\hline HOL & $-.303 *$ & .003 & 1 & & \\
\hline LDL & -.132 & $.736 \star \star$ & -.095 & 1 & \\
\hline TG & $.318 *$ & $.316 \star \star$ & $-.323 \star \star$ & .207 & 1 \\
\hline \multicolumn{7}{c}{}
\end{tabular}

\section{$\mathrm{IV}$. 결 론}

본 연구는 칼슘석회화 수치와 체성분 측정기의 결과 중 체성분, 체지방, 체지방률, 복부비만도와 지질대사 검사결과 중 총콜레스테롤수치, 고밀도콜레스테롤, 저 밀도콜레스테롤, 중성지방의 상관관계 및 평균값 등을 이용해 분석하였다. Calcium-scoring CT에서의 낮은 수 치(0-100) 일 때 인체지수와 지질대사 값을 분석하여 다음과 같은 결과를 얻었다.

첫째, 칼슘 수치에 따른 체성분과 지질대사의 빈도 수를 보면 칼슘수치가 0-100사이에서는 체질량지수와 체지방이 정상치에서 가장 많이 분포하였으나 체지방 률과 복부비만도에서는 표준이상에서 많은 분포를 보 였다. 그러나 칼슘수치가 101이상에서는 체성분 분석 의 결과가 모두 표준범위보다 높은 곳에 많이 분포하 고 있었다. 또한 지질대사의 빈도수에서는 총콜레스테 롤과 저밀도콜레스테롤이 위험군에 많이 분포하고 있 었고 고밀도콜레스테롤과 중성지방은 표준범위에 많 이 분포하고 있었다.
둘째, 낮은 칼슘수치에서 체성분 분석과 지질검사 의 차이검증을 보면 다음과 같은 결론을 도출할 수 있 었다. 칼슘수치가 증가할수록 체성분이 증가함을 확인 할 수 있었고 체질량지수에서 칼슘수치가 11-100구간 에서 과체중으로 나타났고 체지방에서는 11-100구간에 서 표준이상으로 나타나고 체지방률에서는 두 구간 모두 표준이상의 수치로 나타났다. 지질검사에서 칼슘 수치의 증가에 따라 중성지방만이 증가를 이루고 총 콜레스테롤, 고밀도콜레스테롤, 저밀도콜레스테롤 모 두 0-10구간이 11-100보다 높게 나타났다. 칼슘 수치에 따른 체성분과 지질대사의 평균값을 살펴보면 체성분 에서 복부비만도는 세 범위에서 표준수치에 있었으나 수치가 0-10일 때 체질량지수와 체지방률이 표준이상 의 평균값으로 나타나고 수치가 11 이상에서는 체질량 지수, 체지방, 체지방률이 표준이상의 평균값을 나타 냈다. 비만과 심혈관질환의 관계를 볼 때 비만도가 높을수록 심혈관 질환의 발병위험도가 높아진다. 또한 지질대사 분석의 평균값을 살펴보면 칼슘 수치의 전 범위에 걸쳐 총콜레스테롤과 저밀도콜레스테롤의 평 균값이 표준이상으로 나타났다. 여기서 알 수 있듯 칼 슘 수치가 낮음에도 비만판정의 필수 요소인 체지방 률의 평균값이 기준치 이상이고 지질대사 평균값이 표준이상으로 나와 심혈관질환 발생의 위험성이 내재 되어 있음을 알 수 있었다.

셋째, 낮은 칼슘수치에서 체성분 분석과 지질검사 의 상대적 위험률을 보면 다음과 같다. 체성분과 지질 대사 각각의 표준이상의 위험수치에 있는 인원수를 위험군 $(\mathrm{A})$, 정상범위에 있는 인원수를 비위험군(B)으로 두고 상대적 위험률 $(\mathrm{A} / \mathrm{A}+\mathrm{B} \times 100)$ 을 도출했다. 낮은 칼 슘수치에서 체성분은 상대적인 위험률이 $12-75 \%$ 로 나 타났고 지질검사 값은 상대적인 위험률이 $12-59 \%$ 로 나타났다. 이는 칼슘수치는 낮지만 심혈관질환의 발병 률이 잠재되어 있음을 보여주고 있다.

넷째, Cacium-scoring CT와 체성분 분석과 지질검사 의 상관관계를 보면 다음과 같은 결론을 도출할 수 있 었다. 칼슘 수치를 기준으로 체질량지수, 체지방, 복부 비만도 값은 기존 연구에서와 같이 양(+)의 상관관계 를 가지는 유의한 상관관계를 나타내었고 체질량지수 를 기준으로 체지방, 체지방률, 복부비만도 값은 양 $(+)$ 의 상관관계를 가지고 있었다. 체지방을 기준으로 체 
지방률과 복부비만도는 양(+)의 상관관계를 보이고 체 지방율을 기준으로 복부비만도는 양(+)의 상관관계를 나타내었다.

이상의 연구 결과를 종합해보면 체성분 분석에서 칼슘수치가 0-10일 때 와 칼슘수치가 11-100일 때 유의 한 상관관계가 있는 BMI와 WHR을 살펴보면 정상범 위의 빈도수가 많아 평균값이 정상범위에 머물렀으나 $21 \%$ 의 상대적인 위험률이 도출되었으며 지질검사에 서도 유의한 상관관계가 있는 $\mathrm{HDL}$ 과 $\mathrm{TG}$ 를 살펴보면 정상범위의 빈도수가 많아 평균값이 정상범위에 머물 렀으나 $21-40 \%$ 의 상대적인 위험률이 도출되었다. 또한 상관관계가 없는 $\mathrm{BFM}$ 과 $\mathrm{BMR}$ 에서는 표준이상에서 빈 도수가 높아 평균값도 높게 나타났으며 상대적 위험 도가 $31-93 \%$ 로 도출되었으며 지질검사에서 상관관계 가 없는 $\mathrm{TC}$ 가 $200 \mathrm{mg} / \mathrm{dl}$ 이상으로 죽상동맥경화증의 발생이 급격히 증가하여 LDL값이 높게 나타났으며 죽 상경화증의 발생을 억제하기 위해 이미 생긴 죽종에 서 콜레스테롤을 제거하는 작용을 하는 $\mathrm{HDL}$ 의 값도 동시에 증가한 것으로 보인다. 이때의 상대적 위험률 은 43-50\%로 도출되었다. 이것은 칼슘 수치가 낮을 때 에도 심혈관 질환의 발생율이 내재되어 있음을 알 수 있었다. 그러나 본 연구는 남성만을 연구하여 성별에 따른 차이를 알 수 없었으며 대상군이 너무 적어 칼슘 수치를 세분화하여 정량화하기에는 부족함이 있었다. 따라서 향후 낮은 수치에서도 조사대상을 확대하고 검사치에 영향을 미칠 수 있는 여러 인자들을 정량화 하여 분석함은 물론 세분화된 수치를 정립하여 심혈 관 질환의 예방을 위한 세부 가이드라인 제시의 기초 자료로 활용될 것으로 기대된다.

\section{참고문헌}

[1] Mautner SL, Mautner GC, Froehlich J et. al., "Coronaryartery disease: prediction with in vitro electron beam CT", Radilolgy Vol. 192, No. 3, pp. 625-630, 1994.

[2] Rumberger JA, Simons DB, Fitspatrick LA, Sheedy PF, et. al., "Coronary tomography and coronary atherosclerotic plaque area: a histopathologic correlative study", Circulation, Vol. 92, No. 8, pp. 2157-2562, 1995.

[3] Taylor AJ, Bindeman J, Feuerstein I, et. al., "Coronary calcium independently predicts incident premature coronary heart disease over measured cardiovascular risk factors: mean three-year outcomes on the Prospective Army Coronary Calcium(PACC) project", J Am Coll Cardiol, Vol. 46, No. 5, pp. 807-14, 2005.

[4] Shaw LJ, Raggi P, Schisterman E, et. al., "Prognostic value of cardiac risk factors and coronary artery calcium screening for all-cause mortality", Radiology, Vol. 228, No. 3, pp. 826-833, 2003.

[5] Kondos GT, Hoff JA, Sevrukov A, et. al., "Electron-beam tomography coronary artery calcium and cardiac events: a 37-month follw-up of 5635 initially asymp-tomatic low-to intermediate-risk adults", Circulation Vol. 107, No. 20, pp. 2571-2576, 2003.

[6] LaMonte MJ, FitzGerald SJ, Church TS, et. al., "Coronary artery calcium score and coronary heart disease events in a large cohort of asymptomatic men and women", Am J Epidemiol Vol. 162, No. 5, pp 421-429, 2005.

[7] O'Malley PG, Taylor AJ, Jackson JL, et. al., "Prognostic value of coronary electron-beam computed tomography for coronary heart desease events in asymptomatic populations", Am J Cardiol, Vol. 85, No. 8, pp. 945-948, 2000.

[8] Detrano R, Hsiai T, Wang S, et. al., "Prognostic value of coronary calcification and angiographic stenoses in patients undergoing coronary angiography", J Am Coll Cardiol, Vol. 27, No. 2, pp. 285-290, 1996.

[9] Sungwok Park, Hyunju Kim, et. al., "Prevalence of obesity of high school students in jeju island and cardiovascular risk factor", Cheju Journal of Life Science, Vol. 5, No. 6, pp. 23-35, 2002.

[10] Pooling Project Research Group(1978). "Relationship of blood pressure, serum cholesterol, smoking habbit, relative weight and ECG abnormalities to incidence of major coronary events: final report of the pooling project ", J Chron Dis, 31; pp. 201-306, 1978.

[11] Jongduek Lim, Jaeeun Jung, et. al., "Relationship Analysis of Osteoprorosis and Body Mass Index(BMI) in the Middle-Aged Women" Jornal of the Korean Society of Radiology, Vol. 5, No. 6, pp. 365-367, 2011.

[12] Kuylee Park, Yeongchea Cho, " Pressures and Blood Biochemical Properties with BMI in Heath checkup Examinees" Journal of academia-industrial technology, Vol. 11, No. 12, pp. 4843-4853, 2010. 